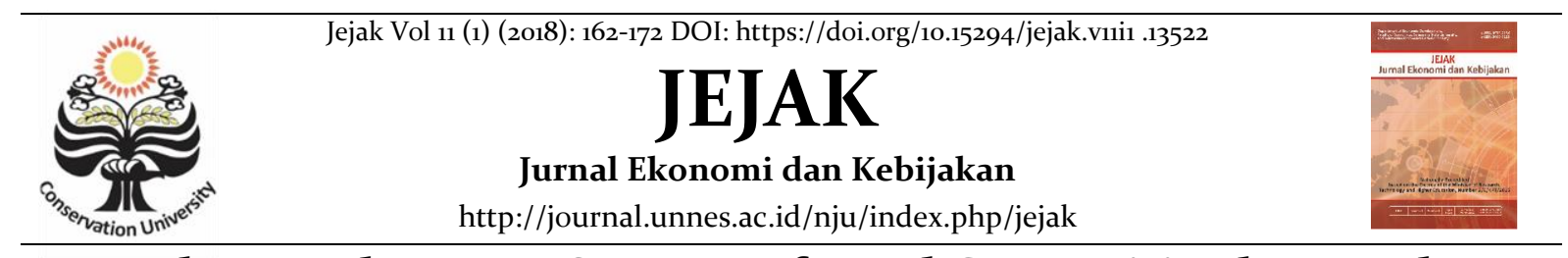

\title{
The Development Strategy of Local Competitive by Metal Industrial
}

\author{
Hadi Sasana ${ }^{1 凶}$, Hastarini Dwi Atmanti² ${ }^{2}$ Dul Muid³ \\ ${ }^{123}$ Faculty of Economics and Business, Diponegoro University \\ Permalink/DOI: https://doi.org/10.15294/jejak.v11i .13522
}

Received: October 2017; Accepted: January 2017; Published: March 2018

\begin{abstract}
In the era of globalized demands readiness state or area to be able to compete. This study dug condition flagship cluster in Central Java that is industrial metal casting in Klaten Regency. Methods of analysis using qualitative and quantitative analysis (R/C Ratio; Analytical Hierarcy Process). Using primary data as well as secondary data collected from selected samples or related institutions. Those results found: (1) the actors cast metal Small medium enterprises (SME) efforts largely have joined in a group/cluster (2). Based on the analysis of the feasibility of the effort, all the effort in the area of the cluster of decent run because it has a value of $\mathrm{R} / \mathrm{C}$ ratio is more than 1 (one) (3). Industrial cluster development priority scale cast metal are: marketing, production aspects, aspects of the infrastructure, institutional aspects, and managerial aspects.
\end{abstract}

Key words Competitiveness ; Metal industry, Cluster, R/C Ratio, Analytical Hierarcy Process

How to Cite: Sasana, H., Atmanti, H., \& Muid, D. (2018). The Development Strategy of Local Competitive by Metal Industrial. JEJAK: Jurnal Ekonomi dan Kebijakan, 11(1), 162-172. doi:https://doi.org/10.15294/jejak.vi1iı .13522 


\section{INTRODUCTION}

Manufacturing industry play an important role in the economy of Indonesia because of its ability to produce products that can be traded and open employment. Therefore, government policies based on local conditions in the manufacturing industry to be important especially in relation to economic globalization in this case Asean economic community(MEA) (Silalahi,2014).

In addition to the need for the acceleration of industrial development in terms of sectoral, need to also there is industrial policy which is spatial/regional policy, for example to improve the independence and equity by giving a chance to the area to set up and manage the entire potential of its resources in order to created a production efficiency and effectiveness (Istifadah 2008).
Small medium enterprises (SMEs) in Klaten Regency had been the base of the economy of the society as hereditary, and played an important role as a pillar of the people's economy in the region. The existence of SMEs in this area becomes a potential sector in boosting the economy of the people being able to give jobs to the local community and beyond (Fereshti et al, 2008).

There are four main types of industrial SMEs in Klaten Regency that influence significantly on the economy areas, namely cast metals, furniture, batik, and pottery. Of the four types of SMES the SME is a metal cast of the most elderly of its existence either at national or regional level. From the origin to ternamanya village of Batur Ceper Subdistrict as a metal casting industry centers in Klaten (Statistics of Klaten Regency, 2014).

Table 1. Objectives, Research Methods, and Research Output

\begin{tabular}{|c|c|c|}
\hline $\begin{array}{l}\text { Research } \\
\text { Goal }\end{array}$ & $\begin{array}{l}\text { Research } \\
\text { Method }\end{array}$ & Output/ Achievement Indicator \\
\hline $\begin{array}{l}\text { Perform the analysis effort in } \\
\text { Metal Industry cluster of } \\
\text { Small Medium Enterprises } \\
\text { cluster in Klaten Regency }\end{array}$ & 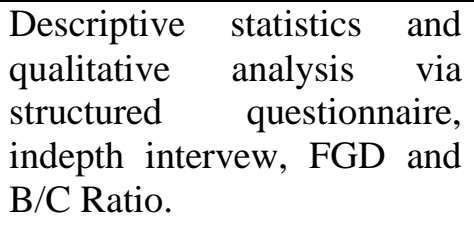 & $\begin{array}{l}\text { Model engineering: potential } \\
\text { competitiveness cluster and } \\
\text { strategic cluster development }\end{array}$ \\
\hline $\begin{array}{l}\text { Strategy the development of } \\
\text { the region through the } \\
\text { application of information } \\
\text { technology cluster strategy- } \\
\text { based communication }\end{array}$ & $\begin{array}{l}\text { Qualitative analysis with } \\
\text { wawacara, FGD, and indepth } \\
\text { interview and quantitative } \\
\text { and Analytic Hierarchy } \\
\text { Process (AHP) }\end{array}$ & $\begin{array}{l}\text { The model of strategy } \\
\text { development through the } \\
\text { application of information } \\
\text { technology cluster strategy-based } \\
\text { communication. }\end{array}$ \\
\hline $\begin{array}{l}\text { Follow up development plans } \\
\text { through } \\
\text { strategies for information } \\
\text { technology communications }\end{array}$ & $\begin{array}{l}\text { Qualitative analysis with } \\
\text { interviews, } \\
\text { FGD, and indepth interview. }\end{array}$ & $\begin{array}{l}\text { Application of strategy of } \\
\text { development of the region through } \\
\text { the application of information } \\
\text { technology cluster strategy-based } \\
\text { communication }\end{array}$ \\
\hline
\end{tabular}

Source : Primary Data Processed 
The internal conditions of the SMEs in the metal casting Batur Ceper currently not fully conducive to SMEs, because not all of the incoming members of the cooperative. This leads to unhealthy price competition, and competition is due payment. Such a condition is actually very detrimental to them, which are supposed to be working together became a partner with the cooperatives, but instead tend to be as a competitor.

The external conditions of the SMEs in the metal casting Batur in terms of competitiveness of products very competitive this result efisiennya the cost of production, so that the selling price of a product can compete with the big companies, because the cost of raw materials cluster were lower than the big companies.

The domestic market is currently the main market in marketing the products of metal casting. The domestic market of the State enterprises include large companies, pengepul, shop tools, household tools, shop machines. However due to some standard products and transportation constraints causing the craftsmen didn't have a lot of options in the market.

According to Sugiarto et al. (2015), the results of the research show that the problems in the industry cluster development is how to manage cooperation between cluster members with industry, Government and institutional supporters. The strategy of innovation and technology is the most important strategy to develop a cluster with a lead actor is supporting institutions. Knowledge management strategy the most important strategies to support innovation and technology strategy is a combination of codification and personalization.

Based on the research of Felzensztein et al. (2012) shows that there is a significant problem in terms of cooperation between the companies and social networking between industry group or groups. The results of this research describes the development strategy cluster with the concept marketing group, further enhance cluster in marketing.

Research Sureephong et al. (2007) produced a model of knowledge management systems to manage export marketing knowledge on ceramic industry cluster of small and medium scale in Thailand with the lead actor is the ceramic industry association (cooperative SMEs) as an important factor in the sustainability of the industry cluster. Chen and Xiangzhen research (2010) produces a model of knowledge management systems to advance the core competence on industrial cluster.

The cluster is a geographic concentration among companies that are intertwined and in collaboration, among others, involve a supplier of goods, providers of services, related industries, as well as a number of agencies that specifically serve as ancillary and complementary or. Relations between the companies in the cluster can be horizontal or vertical.

Horizontal in nature through the mechanism of the complementary service product, the use of a variety of specialized inputs, technology or institution; While the nature of its vertical bar is done through a chain of purchases and sales (Porter, 1998).

Industrial cluster literature shows that, in practice, the approach in the development of industrial cluster can be very diverse. In principle, to be able to develop an industrial cluster, one cannot just imitate what has been done in other industry cluster development. Industrial cluster development should be adapted to the industry in question (including its business offender behavior) and the 
characteristics of local specialties/local (Taufik, 2009).

This study aimed to examine regionbased optimization of cluster development. In detail are as follows: (1) conduct analysis of industrial SMEs cluster effort in Cast metal in Batur Ceper Subdistrict Klaten Regency. (2) formulating the development strategies of industrial cluster through the SMEs area Cast metal in Batur Ceper Subdistrict Klaten Regency (3). Follow up development plans through the cluster strategy.

\section{RESEARCH METHODS}

In line with the objectives of this research, using methods of action research. This study is a research survey to get an overview of the cluster of Small medium enterprises and business model today, following the management mechanism and its prospeknya to the next. Penelitain on do in SMEs cast metal Batur Village Sub-district Ceper and Klaten Regency. In general this research using primary data and secondary data. Primary data will be collected through interviews with respondents who guided by structured questionnaire against the Manager in Small Medium Enterprises cluster and indept interview, as well as FGD (Focus Group Discussion) and related stakeholders. Secondary data obtained through searches of various libraries and documents from various relevant agencies: 1). Department of cooperatives and SMEs of the province and Klaten Regency, 2). Bappeda province and klaten Regency, 3). Central Bureau of Statistics of the province and Klaten Regency, 4). FPSED province and Klaten Regency, 5). Other relevant agencies.

Methods of analysis used in this study are Analytical Hierarcy Process (AHP). The
Method of AHP is a model that was introduced by Saaty in 1993. This decision support model will be Untangling multi factor or multiple criteria into a complex hierarchy. (2) R/C Ratio (Revenue Cost Ratio) is a measure of comparison between earnings (Revenue $=\mathrm{R}$ ) with the total production cost $($ Cost $=\mathrm{C})$.

In terms of quantity value $\mathrm{R} / \mathrm{C}$ it can be known whether a business is profitable or unprofitable. If the $\mathrm{R} / \mathrm{C}$ ratio $>1$, decent effort is carried out and if the $\mathrm{R} / \mathrm{C}$ ratio 1 , effort $<$ unfit or losers (Raharjo, 2007). (3). Indepth Interview is the process of obtaining information for research purposes by way of questioning while face to face between the interviewer with the respondent or theperson who was interviewed, with or without the use of the guidelines (guide) interview where the

interviewer and informant involved in social life is relatively long (Sutopo 2006). This research use approach combined i.e. method mix quantitative and qualitative approaches (Creswell, 2007) research to answer questions and identify phenomena that occur on the SME cluster is closely related to the institutional conditions, competitiveness, as well as increased competitiveness strategy. Based on earlier descriptions presented details of the objectives, methods, and the expected outputs from this study as shown in Table 1

\section{RESULTS AND DISCUSSION}

The six causes of shadow economy, which are government expenditure, fiscal freedom, business freedom, unemployment rate, freedom of labor, and tax rate, show the significant results in shadow economy. With the freedom for the workers and the freedom to do business given by the government, the 
shadow economy activity among the people will be smaller. The tax rate also influences the formation of the shadow economy. This also strengthens the previous research, which suggests that one of the driving factors of the emergence of shadow economy is a high tax and labor regulatory issues.

Based on the estimated results, the average shadow economy in ASEAN has increased slowly starting from 2012. Its growth is moving at the level of $27 \%-29 \%$ of GDP. Countries with shadow economy rates above the average of ASEAN are Thailand, Cambodia, Malaysia, Laos, and the Philippines. In general, shadow economy has not changed significantly since 2007. The biggest change occurred in Thailand where the shadow economy has decreased more than other countries. The development of shadow economy in ASEAN countries is presented in this graph.

Analysis of the venture through its profitability aims to measure the company's ability to obtain a profit, both in relation to sales, assets, as well as its own capital. So the results of profitability can be used as a benchmark or a picture of the effectiveness of the performance of the business in terms of profits compared to the overall cost.

Financial statements such as balance sheet, profit-and-loss report cash flow are analyzed using the analysis tool that suits the needs of analysts.

The process of processing the input into the output in metal casting cost that varies, depending on the vulome effort and the condition of the economy. Costs in metal casting in Batur Ceper Subdistrict consists of fixed costs (fixed cost) and variable costs (variable cost). An overview of the total costs incurred by SMEs Ceper Subdistrict metal casting for one month can be seen in table 2 with the assumption the age of fixed cost is five years or 60 months. Acceptance in the business of metal casting is the value received from the proceeds of sale of metal products. The value of money received entrepreneurs retrieved from the results of the multiplication between the amount of product produced during a month with the unit price of the product. Table 3 is a portrait of the results of the acceptance is received by the employers of metal casting that is amounting to $\mathrm{Rp} 56,500,000$ per month. Details of acceptance can be seen in table 3.Profits in the business of metal casting is the value accepted by employers and is the acceptance by the entire difference between the total costs incurred. Profit earned in metal casting business reached IDR 16,958,333 per month

$$
\begin{aligned}
\Pi \quad=\text { Rp.56.500.00o }-\mathrm{Rp} \cdot 39 \cdot 541.667 \\
=\text { Rp.16.958.333 }
\end{aligned}
$$

Analysis of the Feasibility of the Venture Metal Casting, feasibility analysis of effort of metal casting using the method of return/cost analysis. This method is done by comparing the total acceptance by the total cost. If the value of $\mathrm{R} / \mathrm{C}$ greater than $\mathrm{i}$ then the effort deserves to be executed. In calculating the $\mathrm{R} / \mathrm{C}$ ratio in the business of metal casting using the assumption of land area used $500 \mathrm{~m} 2$ with the status of ownership and buy the assumption of fixed costs was 5 years or 60 months.

$$
\frac{\mathrm{R}}{\mathrm{C}} \text { ratio }=\frac{\mathrm{Rp} 56.500 .000}{\mathrm{Rp} 39.541 .667}=1,43 .
$$

The value of $\mathrm{R} / \mathrm{C}$ ratio resulting from the pattern in metal casting business in Ceper Region i.e. of 1.43. This shows that with production costs of $\mathrm{Rp} 39,541,667$ will result in the acceptance of 1.438 times larger in one month, in other words any $\mathrm{Rp} 1$ production costs incurred will result in acceptance of $\mathrm{Rp}$ 1.43 in a month. 
Table 2. The List Details The Total Cost

\begin{tabular}{lll}
\hline Cost & Total Cost (Rp) & Total Cost/Mounth (Rp) \\
\hline Fix Cost & & 3.791 .667 \\
\hline Fixed cost/mouth & $\mathbf{2 2 7 . 5 0 0 . 0 0 0}$ & 39.541 .667 \\
\hline Source: primary & - & .
\end{tabular}

Source: primary data, processed by 2017. ${ }^{*}$ Assuming a fixed age is 5 years or 6o months

Based on a calculation of the ratio $\mathrm{R} / \mathrm{C}$ can be said to be decent metal casting business run because it has a value of $\mathrm{R} / \mathrm{C}$ ratio $>1$.

The strategy of the development of the region through the cluster SMEs Industries Cast metal, based on the results of the indept interview with with stakeholders related to cluster development cast metal in the area of research, there are several main aspects that need to be taken care of, namely: (1) aspects of the production, the marketing aspect (2), (3) managerial aspects, (4) aspects of the infrastructure, and (5) the institutional aspect. The fifth aspect is the next major factor in SMEs cluster development efforts of cast metal in the area of research. Small Medium Enterprises cluster development strategy for metal casting Ceper Subdistrict in formulated based on indepth interviews with key Person who analyzed using AHP with a software Expert Choice version 11.0.
The first phase is done in this research is the analysis of the main aspects in the framework of the SMEs cluster development of metal casting in Batur Ceper Subdistrict according to the key person (academics, businessmen, community leaders Sudi Taylor et al. (2007) shows four factors that significantly influence the success of the cluster, namely: 1) entrepreneurial character 2) well calculation 3) innovative, and 4) the courage to take risks The results of the analysis as shown in Figure 1.

Based on Figure 1 it can be seen that the order of priorities according to the main aspects of the key-person to develop metal casting in Batur Ceper Subdistrict, namely the marketing aspect of $\mathbf{1 9 . 2}$ percent. Then manjerial and institutional aspects of each of the same aspects of 19 percent, production of $11.0 \%$ percent, and infrastructure aspects of 13.4 percent.

Table 3. The List Details The Admission

\begin{tabular}{llll}
\hline Product & Quantity (Unit) & Price $(\mathrm{Rp})$ & Total Revenue $(\mathrm{Rp})$ \\
\hline Roda pintu & 1000 & 6000 & 6.000 .000 \\
Kerekan timba & 500 & 11000 & 5.500 .000 \\
Sparepart mesin & 1000 & 20000 & 20.000 .000 \\
Poli mesin & 1000 & 25000 & 25.000 .000 \\
\hline Total Revenue & & & 56.500 .000 \\
\hline
\end{tabular}

Source: Primary Data, processed by 2016 
Priority with respect to:

Goal - Development Cluster UMKM Klaten District

Marketing

Managerial

Instutional

Production

Infrastructure

Inconsistency $=0.25$

With o missing judgments

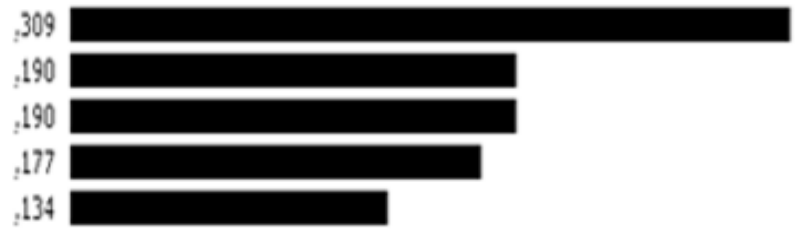

Figure 1. Analysis of the main Aspects in the development of metal casting Small Medium Enterprises cluster development in the village of Batur Ceper Subdistrict Klaten Regency.

Source: Primary data processed, 2017.

Overall, based on the results of the analysis in order to cluster development SMEs Ceper Subdistrict in metal casting according to respondents have a similar view of the main aspects related that should be enhanced i.e. aspects of marketing. According to the cluster administrators as Sriyanto reveals, the main needs faced by the cluster is currently the marketing strategy, branding. To a good distribution process in order to be able to harness the potential of demand growth that gets bigger.
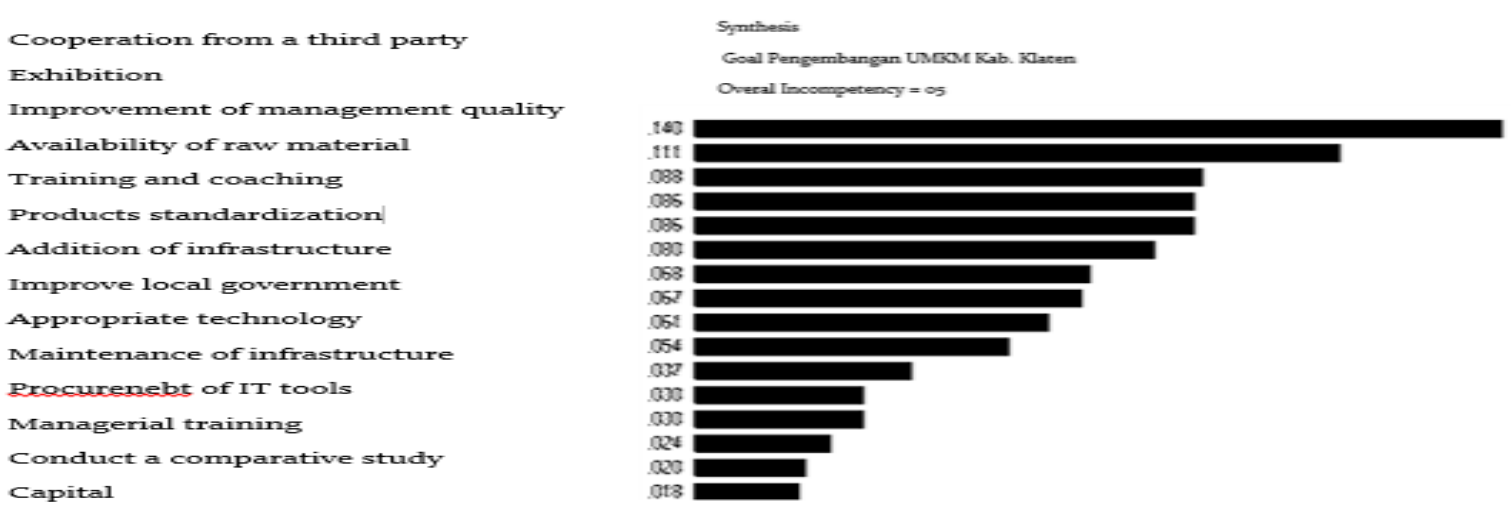

Figure 2. Analysis of the Policy Priorities in the development of Small Medium Enterprises cluster development of metal casting in Batur Ceper Subdistrict Klaten Regency.

Source: Primary data, processed, 2017

The next stage is done in analyzing the development policies of SMEs cluster development of metal casting in Batur Ceper Subdistrict, namely analyzing the overall policy strategy priorities based on the aspects and policy alternatives that are used in this research.
Altuntas et al. study (2014) showed that the work planned and organized is the concept of the various facets of which are operational expenditures and financial expenses. The results of the analysis of the overall priority according to key-person can be seen in Figure 2. 
Table 4. Small Medium Enterprises (SMEs) Cluster Development Plans Follow The Cast Metal Ceper Subdistrict

\begin{tabular}{|c|c|c|}
\hline Action Plans & Targets & Relating Implementer \\
\hline $\begin{array}{l}\text { Strengthening Cooperation } \\
\text { and repair Agencies Cluster }\end{array}$ & $\begin{array}{l}\text { Improve Marketing and } \\
\text { quality cluster }\end{array}$ & $\begin{array}{l}\text { Cluster, Bapedda, Disperindag } \\
\text { cooperatives and Small Medium } \\
\text { Enterprises }\end{array}$ \\
\hline Improved Product Quality & $\begin{array}{l}\text { Improve the quality, } \\
\text { standards and product } \\
\text { safety }\end{array}$ & $\begin{array}{ll}\text { Cluster, Bapedda, } & \text { Polman, } \\
\text { Disperindag and Small } & \text { Medium } \\
\text { Enterprises and R \& D } & \end{array}$ \\
\hline Increase Production Capacity & $\begin{array}{l}\text { Improving the capacity } \\
\text { and scale of business }\end{array}$ & $\begin{array}{l}\text { Cluster, Bapedda, Disperindag and } \\
\text { Small Medium Enterprises and } \\
\text { Polma }\end{array}$ \\
\hline $\begin{array}{l}\text { Improvement Of Quality } \\
\text { Management }\end{array}$ & $\begin{array}{l}\text { Enhance the professional } \\
\text { business }\end{array}$ & $\begin{array}{l}\text { Cluster, Disperindag and Small } \\
\text { Medium Enterprises }\end{array}$ \\
\hline $\begin{array}{l}\text { The creation of a conducive } \\
\text { business season }\end{array}$ & $\begin{array}{l}\text { Fluency and enterprise } \\
\text { development as well as the } \\
\text { interests of investors }\end{array}$ & $\begin{array}{l}\text { Cluster, Bapeda and Disperindag } \\
\text { and Small Medium Enterprises }\end{array}$ \\
\hline
\end{tabular}

\section{Source: Primary Data Managed, 2016}

According to figure 2, the results of the consistency of the whole policy priorities analysis ratio i.e. amounting 0.05 , meaning the results of this analysis are consistent and acceptable. Three top policy priority order according to the respondents, namely 1.) marketing cooperation with third parties amounted to 14 percent, 2.) exhibitiom of 11.1 percent and 3.) e-commerce amounted to 8.8 percent. Cooperation with third parties in marketing such as the signing of the purchase contract is very effective in cluster development.

This is because with the cooperation it does purchase would give certainty to employers about what products are manufactured, the quality required and provide certainty of the price. The priority of the next strategy is to do the exhibition will be able to introduce processed metal products Ceper to society. E-commerce a priority next, due to the growing technology especially the internet ecommerce then become effective media in introducing and marketing the products of refined metal.

The cluster system can create a business network structure among parties involved in the production of goods or services, it can be taken into account as one of the models of increasing regional development (Söylemezoğlu, 2014). The plans follow the development of the region through the cluster SMEs Industries Cast Metal, based on the selection of priority policies using AHP (Analytical Hierarcy Process), next is drawn up plans follow up Cast Metal Small Medium Enterprises cluster development in district Ceper.

Table 4 shows the follow-up plans, goals and relevant parties in an attempt to follow up implementation plans Strengthening cooperation is focused to improve marketing 
and quality cluster. Efforts in boosting cooperation should be initiated from the internal cluster i.e. cooperation between cluster.

The members of the cluster working together will be able to provide products of cast metal terstandar and keeping stock of the sustainable production of metal and has a bargaining position in the determination of prices, so that it will be mutually beneficial against fellow members of the cluster.

Product quality needs to be improved and should be terstandar in order to have the competitiveness in the market. Starting from the cluster members can cooperate each other maintain the product quality metal cast every Member, so that each Member of the cluster is no different the quality of its products. Agencies like Bappeda, Polman, R \& D, Disperindag SME's should take on the role both in maintaining the quality of cast metal cluster products. The most important efforts in the form of training, training production here not to teach the ways of metal, but mengecor information product physical characteristics and composition standards prevailing in the market. Innovation was becoming attraction for tourists, and generate benefits to the economy of the local more real (Schmitz and Spencer, 2006).

The increase in production capacity itself is simply the impact of an increase in product marketing, when marketing on the rise then any production capacity should be increased. The increase in production capacity can be taken in two ways, namely the addition of the factors of production or production factors pengefisienan. For short pengefisienan of the factors of production is chosen, because the cost is not great. Efficiency is meant more to the
SOP in the production process, by expected production process SOP will be more efficient. Understanding of SOP need mentoring and an explanation of the Disperindag SME's and Bappeda. For the long-term addition of factors of production is the right choice, in addition will add production capacity also regenerate production factors that are out of date.

Quality management is synonymous with human resources, resulting in improving the quality of management then should improve the quality of human resources. Human resources in a cluster of metal cast is divided into two parts, namely the field of managerial and technical. Target quality improvement management here is a professional effort of human resources both in managerial or technical level. Individual companies, Cast Metal Cluster urgency is in production management and finance, while the marketing management is a shared task. Cast Metal Cluster production management is still fairly simple and based on the order, then it needs to be improved especially in the manufacture of SOP production, so efficient and production costs incurred can be pressed. Financial problems in cast metal cluster mainly in capital for sustainability efforts, this happens because the system of payments due, so many entrepreneurs who stopped production until the due date of payment. Need help with sharing between cluster together and Disperindag Small Medium Enterprises by providing managerial science required the members of the cluster.

The condition of the business climate in cast metal cluster is somewhat less well, shown by not all members of the cluster are members of cooperatives there are even out of the cooperative members, although several 
members of the cluster working together but not in a formal cooperative-like container. Such a situation was actually a detriment, especially in product quality, pricing because it is done individually. Local governments such as Department of Industry and Trade. Regional Development Planning Board needed to mediate and unite under one roof cast metal cluster. If the Cast metal cluster unified then the business climate will be more conducive, this will facilitate the provision of raw materials, product availability and marketing so that investors or companies would be interested in cooperation with Cast Metal Cluster.

\section{CONCLUSION}

. Based on the results of research and analysis of the condition of the metal casting industry cluster in Klaten Regency, can be summed up as follows analysis of business profitability cast metal business in the village of Batur Klaten decent run because it has a value of $\mathrm{R} / \mathrm{C}$ ratio more than one, the priority Scale metal industry cluster development are: marketing, production aspects, aspects of the infrastructure, institutional aspects, and managerial aspects. Sales cooperation with third parties become the most optimal strategy in developing a cluster of Small Medium Enterprises. The priority of the strategy is further exposition, with exhibits of products processed metal Ceper Subdistrict at events or other Government will introduce the public to the metal products and can bring together a network of mutual support in this endeavor. The third strategy is a priority then the ecommerce because it saw the rapid development of the internet, the perpetrators of the SMEs should follow. Plan follow up the development of the region through the cluster
SME Industrial metal in Klaten Regency, namely by means of (a). Increased cooperation (b). The improvement of the quality of the product (c). The increase in production capacity (d). (Improved Quality Management) (e). The creation of a conducive business climate.

\section{REFFERENCES}

Altuntaş, GültekinSemerciöz, Fatih. Mert, Aslı and Pehlivan, Çağlar .2014.Industri Forces, Competitive dan Functional Strategies and Organizational Perfomance: Evidence from Restaurant in Instanbul Turkey.Social and Behavioral Sciences Vol. 150 page 300-309.

Chen, Zhenfeng, and Xiangzhen X. 2010. Study on Construction of Knowledge Management System Based on Enhancing Core Competence of Industrial Clusters. International Journal of Business and Management Vol. 5 (3) page 217-222.

Creswell, John W, and Clark,Vicki L. Plano. 2007. Designing and Conducting Mixed Methods Research 2nd Edition. University of NbraskaLincoln.

Felzensztein, Christian. Eli, Gimmon and Aqueveque, Claudio. 2012. Clusters or un-clustered industries? Where inter-firm marketing cooperation matters, Journal of Business \& Industrial Marketing, Vol. 27 Iss: 5 , pp. $392-402$

Fereshti, N.D. Saputro, Purwo Edy. and Purnomo, Didit 2008. Strengthening Cluster Capacity of Small and Medium Enterprises: Case In Serenan, Klaten. Journal of Development Economics, Vol. 9, No.1, page 83 - 95

Istifadah, Nurul. 2008. Developing Industry Development Strategy in East Java Facing the Global Era. Download

https://myslide.es/documents/20-strategipengembangan-industri-pengolahan.html

Porter M.E. 1998. Clusters and New Economics of Competition. Harvard Business Review Vol.76, no. 6 page $77-90$.

Raharjo, Ferianto. 2007. Economic Analysis of Decision Making Techniques, Yogyakarta: Andi.

Saaty, Thomas L. 1993. The Analytical Hirarchy Process. USA: Mc. Graw-Hill. 
Schmitz, Birte and Trisha Spencer.20o6." Networks, clusters and innovation in tourism: A UK experience".Tourism Management, Vol 7 page 1141 $-1152$.

Silalahi, Sahat Aditua F. 2014. Manufacturing Industry Condition in Indonesia against Globalization. Journal Economics Public policy, Vol 5, No 1 page 1-13

Söylemezoğlu, Ergül and Doruk, Ömer Tuğsal. 2014. "1oth International Strategic Management Conference Are Clusters Efficient For The Relation Between Milk Production And Value Added Per Capita In Regional Level? An Empirical Assessment". Procedia - Social and Behavioral Sciences Vol.15o, page 1277 - 1286.

Statistics of Klaten Regency.2014. Group of Industy and Total Unit Effort by Classify of Effort in Klaten Regency 2014

https://klatenkab.bps.go.id

Sugiarto, Dedy, Ma'arif, M. Syamsul. Sailah,Illah. Sukardi and Honggokusumo,Suharto. 2015. Selection of Industry cluster Development Strategy and Knowledge Management Strategy at Latexdpped Goods Industrial Cluster. Jurnal Teknik Industri Pertanian, Vol. 20 page 89-100.
Sureephong, P. Chakpitak, Nopasit. Ouzrout, Yacine and Neubert, Gilles. and Bouras, Abdelaziz. 2007. Knowledge Management System Architecture for the Industry Cluster. Proceeding the International Conference on Industrial Engineering and Engineering Management (IEEM 2007). Singapore. <hal-oo196486>.

Sutopo. 2006. Qualitative Research Methodology. Surakarta: UNS.

Syahruddin. 2010. Evaluation of Policy Implementation of Industrial Estate Development. Journal of Administration and Organization Science. Journal of Administration and Organization Science, Volume 17, Number 1, p. 31-43.

Taufik, T.A. 2009. Policy Perspective: Industrial Cluster Approach In Regional Competitiveness, Yogyakarta: BPFE.

Taylor, Peter. Williams, Pam McRae and Lowe, Julian.2007. The Influence of Industrial Clusters and Place on Innovation and Entrepreneurial Behaviour An Empirical Analysis of the Australian Wine and Tourism Industries. The International Journal of Entrepreneurship and Innovation. Vol.13 issue 4 page 639-649. 